\title{
Flood Impacts Analysis and Mitigation Approach towards Community Resiliency at Nageshwari Upazila, Kurigram
}

\author{
Most. Nusrat Binte Nur ${ }^{1 *}$, Md. Abdur Rahim ${ }^{1}$ and Md. Rasheduzzaman ${ }^{2}$ \\ ${ }^{1}$ Dept. of Disaster Resilience and Engineering, Faculty of Environmental Science and Disaster Management, Patuakhali \\ Science and Technology University, Patuakhali, Bangladesh; ${ }^{2}$ Dept. of Emergency Management, Faculty of Environmental \\ Science and Disaster Management, Patuakhali Science and Technology University, Patuakhali, Bangladesh. \\ *Correspondence: nusratdre@pstu.ac.bd (Most. Nusrat Binte Nur, Lecturer, Dept. of Disaster Resilience and Engineering, \\ Patuakhali Science and Technology University, Patuakhali, Bangladesh).
}

\begin{abstract}
Nageshwari is an upazila of Kurigram locality of Bangladesh. It is one of the most vulnerable areas to flood disasters. Every year many devastating floods occurred in this area. One of the main purposes of the study is to identify flood hazards and their impacts on the people's perception of the study area. Another purpose is to recognize mitigation approaches (both scientific and indigenous practices). To complete the aim, semistructured questionnaires are used. Besides some key informant interviews and focus groups, discussions are also used to validate the collected data. The key findings of the study are the larger impact of inundation on health, agriculture, fisheries, road and transport, water and hygiene, and housing. From the overall impacts in the study area, the most affected sector is agriculture and roads. From people's perception, many problems are found due to devastating floods. Unemployment, food scarcity, communication problems, etc. are the common problems in the study area. People practice some indigenous knowledge to reduce the flood impacts. Scientific practices are also applied by the authority to mitigate the flood impacts. But these mitigation measures are not enough toward accomplishes the demand. Some appropriate measures must be needed to decrease the flood impacts. Early warning systems and information dissemination on floods are not well developed. Sufficient and frequent training is needed about proper flood management, early warning, and dissemination within the lessons area. People take some adaptation techniques to diminish the flood. The local Government also takes some initiatives to decrease the flood impacts. But proper flood management needs to be improved to decrease the flood impacts. Proper management and awareness-raising programs will reduce the impact of inundation to enhance the community resiliency of the area.
\end{abstract}

Keywords: Flood impacts, Mitigation, Indigenous practices, Early warning, Dissemination, and Resiliency.

\section{INTRODUCTION:}

Due to geographical and regional location, Bangladesh is vulnerable to natural disasters (Nasreen et al., 2013). About $92.5 \%$ of the area of three basins lies outside the boundaries of the country. Bangladesh is possibly the most flood prone country in the world (Rahman et al., 2013; Cutter, 1996). More than $80 \%$ of the annual UniversePG I www.universepg.com precipitation of Bangladesh occurs in the monsoon period between June and September (Mirza, 2003). Recurrent flooding, drought, cyclones, bank erosions, earthquakes, etc. is extremely common during this country (Ali, 1996) however flood is that the largely occurred incidence among them (Few et al., 2004). The frequency and strength of natural hazard are grow- 
ing day by day comparable to the climate change (Rahman et al., 2014). Among all natural disasters, floods are the most repeated to be faced by Bangladesh (Mohapatra et al., 2003). Third world countries like Asian country area unit the foremost frequent victims of natural disasters, several of that have a serious negative impact on the society (Torry et al., 1979). Peoples of Bangladesh are directly or indirectly affected by natural extreme events. Climate change directly influences natural hazards (especially flood and drought) frequency (Mirza, 2007). Bangladesh is one of the most flood prone countries in the world. Analysis indicates that about $21 \%$ of the country is subjected to annual flooding and an additional 42 percent is at risk of flood with varied intensity (Ahmed, 2000). There are no taxonomic records of annual floods available in Bangladesh. The floods of 1954, 1955, 1974, 1987, 1988 1998, 2004 and 2007 all caused monumental damages to properties and extensive loss of life. The floods of 1987, 1988, 1998, 2004 and 2007 flood caused heavy damage (Hossain et al., 2012).

In recent years the frequency of abnormal floods in Asian nation has hyperbolic well, inflicting serious injury to lives and property. The significant monsoon waterspout and synchronization of flood-peaks of the most important rivers area unit typically thought of to be the most causes of the floods (Khalequzzaman, 1994). Flood is a natural common disaster in our country and northern part of Bangladesh is vulnerable for flooding (Islam, 2017). A Flood is an unusual high stage of a river due to runoff from rainfall and / or melting of snow in quantities too great to be confined in the normal water surface elevations of the river or stream, as the result of unusual meteorological combination (Raghunath, 2009). Water related natural hazards as well as weather change issues have become a serious threat to the lives, livelihoods and sustainable development of Bangladesh (Hakim, 2012). Flood losses scale back the assets of households, communities and societies through the destruction of standing crops, dwellings, infrastructure, machinery and buildings, with the exception of the tragic loss of life. In some cases, the impact of utmost flooding is dramatic, not solely at the individual ménage level, however conjointly within the country as an entire (Rahman, 2014). Flood impacts are large in the Kurigram dis- tricts. A normal mual flooding may be a fascinating event among farmers of the region since it commences at the proper time for cultivation Associate in nursing lasts for an applicable length of your time to profit paddy rice and alternative major crops. Further, the native conditions of settlement and housing, agriculture, and physical infrastructure will typically face up to a traditional flood of restricted severity (Haque, 1993). Flood becomes regular feature in revering Bangladesh (AM et al., 2003). In the Nageshwari upazila, Kurigram is one of the most vulnerable areas to flood disasters. Every year devastating flood is occurred in this area. In this space, the economy is based totally on the land, with the bulk of the country's population used within the agricultural sector. Flood impacts are many in agriculture sector. Primary impacts of flood embody loss of life, harm to property, destruction of crops, loss of placental and destruction of physical condition. Secondary impacts may include with short term pollution of rivers, hunger and diseases and displacement of persons who have lost their homes. Poor People face many problems be-cause they are totally workless in the time of flood (Banerjee, 2007). A maximum community person faces greater difficulties in regulating to a given failure of earnings (Ravallion, 2000).

People practice some indigenous knowledge to reduce the flood impacts. Scientific practices also applied by the authority to mitigate the flood impacts. But this mitigation measures is not enough to accomplish the demand. Some appropriate measures must be needed to decrease the flood impacts. The community people are less capable of taking protective measures against hazards (Varley, 1994). Floods cannot be prevented but their devastating effects can be minimized if advance warning of the event is available (Sinclair, 2003). Structural as well as non-structural procedures are being emphasized for flood management in Bangladesh (Rahman et al., 2014). Keeping the above things in consideration this study tries to identify the flood impacts and mitigation approaches in the study area and improve the organization system of flood. When all the impact of inundation is minimized that time the community will be resilient. When all problems are identified that time flood impacts are quite less rather than past. Proper management and 
awareness raising program will reduce the impact of inundation. Early warning dissemination system and understanding level of warning is a consider factor in the study area. This lesson is designed to identifying and analyzing flood hazard as well as its impacts identify and analysis mitigation approaches, and build community resiliency to flood within the lessons area. Government of Bangladesh could be taken necessary steps to decrease overflow impacts and proper mitigation measures for less flood losses.

\section{The objectives of the study}

The study has three major objectives. This are:

- To identify and analyze the flood hazards and its impacts of the community

- To identify and analyze flood mitigation approaches (both scientific and indigenous practices) at the area

- To build community resiliency to flood

\section{METHODOLOGY:}

Study area - For this study, Nageshwari upazila in Kurigram district was selected. Bamandanga, Berubari, Kachakata and Ballaverk have Union under Nageshwari Upazila selected as the study area. Nageshwari Upazila, Kuri-gram is one of the most vulnerable areas to flood disasters. Every year devastating flood occurred in this area. Flood impacts are many in agriculture sector. The upazila occupies an area of $417.56 \mathrm{sq} . \mathrm{km}$. including 26.53 sq. $\mathrm{km}$. Riverine area. It is located between $25^{\circ} 59^{\prime}$ and $26^{\circ} 13^{\prime}$ north latitudes and between $89^{\circ} 35^{\prime \prime}$ and $89^{\circ} 52^{\prime}$ east longitudes. The upazila is bounded on the north by Bhurungamari Upazila and West Bengal State and Assam State of India, east by the river Brahmaputra and Assam State of India, south by Kurigram Sadar Upazila and west by Phulbari Upazila and West Bengal State of India. The upazila consists of 1 paurashava, 9 wards, 81 mahallas, 14 unions, 73 populated mauzas, and 350 villages (BBS Community report, 2011).

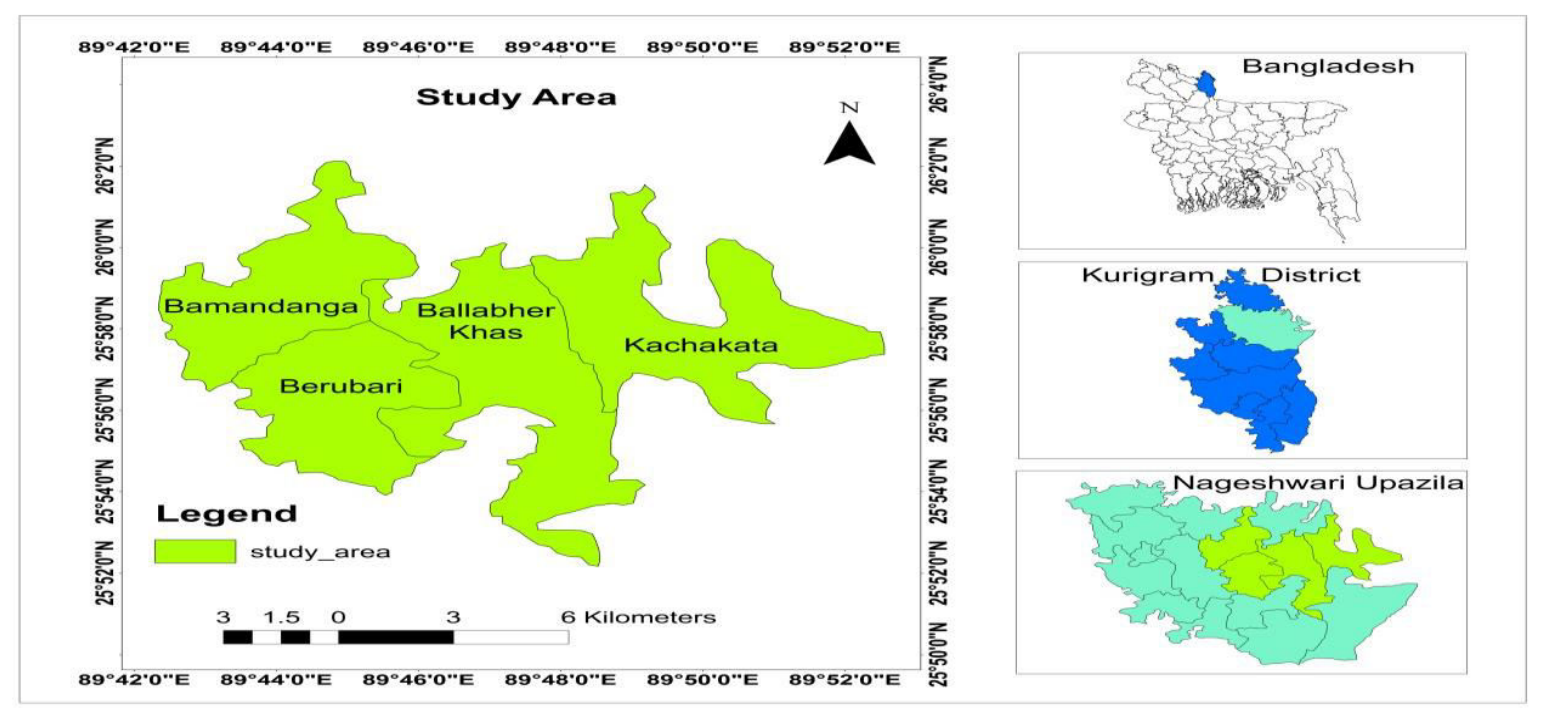

Fig 1: Location map of the study area (Source: LGED, Bangladesh and Using Arc GIS software version 10).

Applied Methodology - It is vital to possess valid method to conduct a study. The authors have utilized equally qualitative and quantitative strategy to accomplish objectives of this research. To begin with, qualitative analysis involve 100 household survey at $95 \%$ confidence level. On the other hand, quantitative analysis have been diagnosed with Microsoft excel data analysis software. Moreover, the stuy area map is prepared by the help of Arc GIS 10.5. Finally, sample size calculation equation reveals in equation (i). Sample size calculation equation is elucidate by -

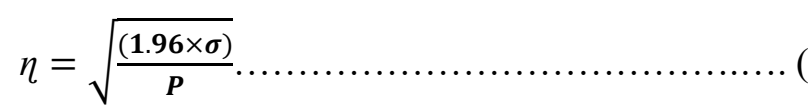

Where, $\sigma=$ standard deviation, $\eta=$ sample size, $P=$ proportion to be estimated $=0.5, \mathrm{t}=1.96$ at $95 \%$ confidence level.

The minor information was mainly collected from various books and journals, encyclopedia. The statistical information was also collect from the union parishad, Upazilla parishad, journals and internet base. 
Secondary data were attained from literature review from published sources such as books, journals, reports, thesis papers etc. Contextual data regarding to hazards and effects pattern has been done by local government, especially from union parishad, Bangladesh Water Development Board (BWDB), Bangladesh Bureau of Statistics (BBS), and Local Gov't Engineering Department etc. In this quantitative data, the total population of the village, educational level, main crops, main income source of that village are collected.

\section{RESULTS AND DISCUSSION:}

Household Types - Within the lessons region the majority of the citizens exist in tin shade house (Fig 2) those are very vulnerable to any disasters. Housing structure is not better for living home when a devastating flood attacked within the lessons part. Starting the analysis, it is showed that $25 \%$ houses are kacha, made with bamboo, straw, and old tins to build a onetime shelter. $45 \%$ houses are tin shade house which are made with tin and wood. The housing condition of the respondents is not good but better than kacha. Only $18 \%$ houses is pucca house, made with brick. As they displace several times because of erosion and siltation, they don't have ability to develop their housing condition. $12 \%$ houses are other types such as jhupri. From the study it is clear that flood has negative impacts on household. Housing structure is a fact to reduce the impact of inundation (Moniruzzaman et al., 2014). In study area most of the houses are tin shade and kacha. So the people are vulnerable for any disasters because this kacha and tin shade houses cannot resist the flow of water.

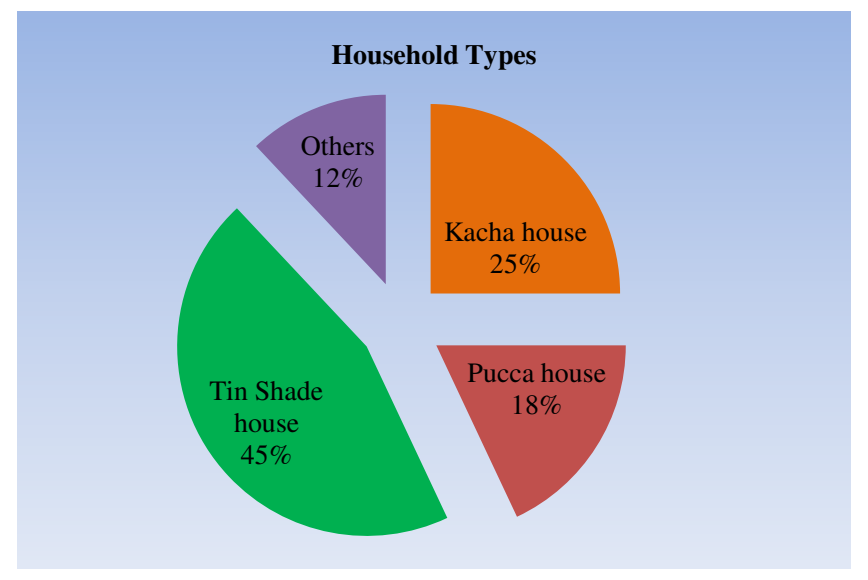

Fig 2: Household types within the lessons area (Source: Field Survey-2019).
Living period of the respondents and experience on flood disaster - Bangladesh may be a terribly flood prone country: common fraction up to common fraction is being flooded throughout the monsoon amount (Brouwer et al., 2007). The people who possess a long living period within the lessons area cover a huge experience on flood disaster. Among the respondent's twenty percent reside during this space from 3-5 years, thirty percent respondents reside during this space from 6-10 years, thirty two percent respondents reside during this space from 11-20 years, eighteen respondents reside during this space over twenty years. Living time of the respondents within the lessons part is given below (Fig 3). Kurigram could be a tiny district in Northwest Bangladesh that ex-periences a high risk of sudden flooding and stream bank erosion within the study space, seventy fifth folks have an excellent expertise on flood disaster and twenty fifth folks don't have any expertise on flood disaster. People are more susceptible for this flood disaster. Most of the realm gets submerged throughout the monsoon that features a vast impact on lifestyle.

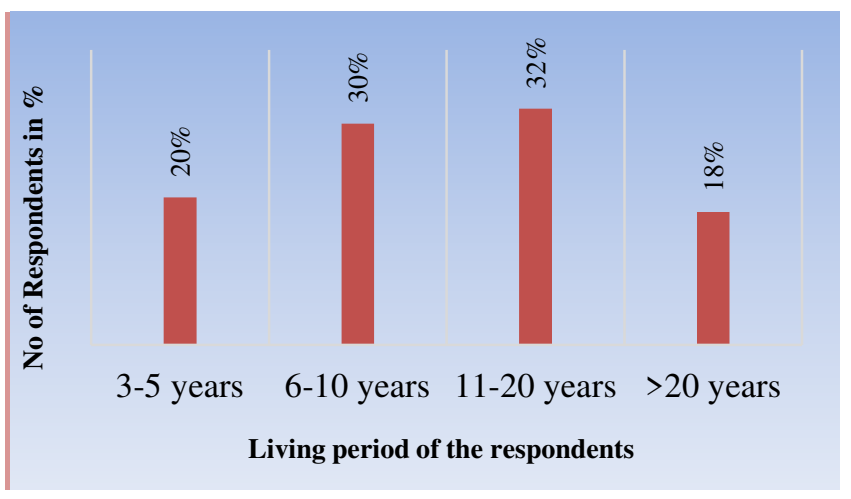

Fig 3: Living time of the respondents at the lessons part (Source: Field Survey-2019).

Types of flood - A flood is an overflow of water that submerges land that is usually dry. A flash flood may be a sudden rush of water over solid ground, typically caused by loads of rain. Flash floods most frequently occur in unremarkably dry areas that have recently received precipitation; however they'll be seen anyplace down-stream from the supply of the precipitation, even several miles from the supply. Rain fed flood sometimes called urban flooding causes unpaid to restricted heavy rains in a day over the city or large town. Flood types within the lessons area are given below (Fig 4). From the sector survey, fifty percent 
individuals' afore said flash floods square measure occurred during this space. $32 \%$ people said about river flood. $15 \%$ people said rain fed flood are occurred within the lessons area. 5\% people said about other types of flood. Flash flood is one in all the devastating natural disasters within the northern region of Bangladesh. Nageshwari Upazila is a probable flash flood occurrence zone.

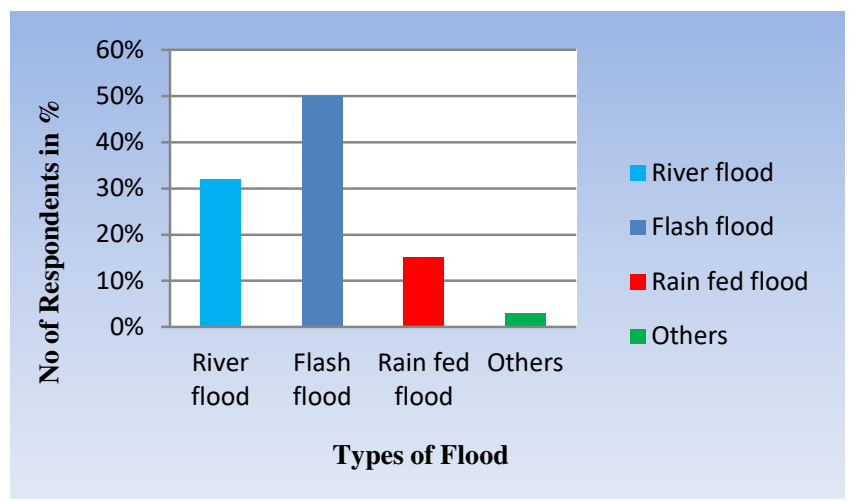

Fig 4: Types of flood within the lessons area (Source: Field Survey-2019).

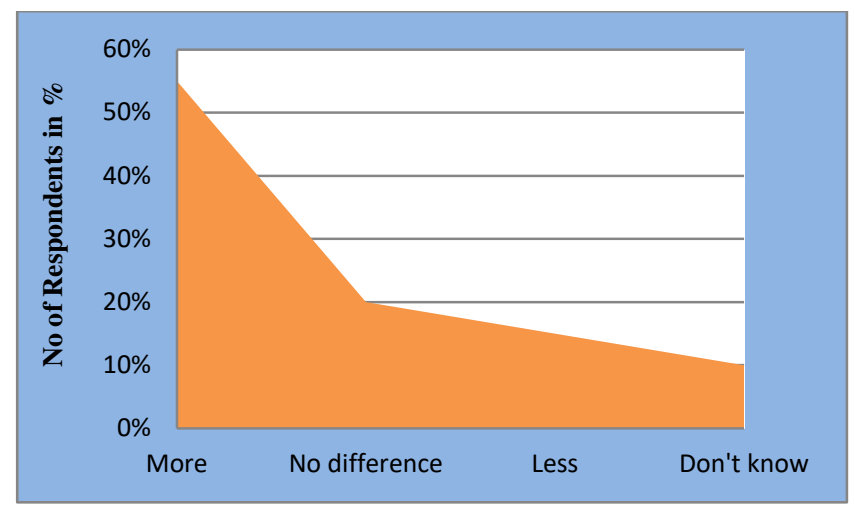

Fig 5: People's perception on flood frequency in last 10-12 years (Source: Field Survey-2019).

People's Perception on flood - Bangladesh is one in all the foremost flood prone countries within the world. Floods are becoming more frequent in the last 10-12 years (Fig 5). Bangladesh faces flood every year. In early October 2005, dozens of villages were inundated when rain caused the rivers of northwestern Bangladesh to burst their banks. Floods also occurred in 2015, 2017 and 2018. From the people's perception and statistical report it is clear that floods are becoming more frequent rather than past. 55\% people said floods are extra frequent in last 10-12 years. $20 \%$ people said there is no difference between present and past. $15 \%$ people said floods are less frequent and $10 \%$

UniversePG I www.universepg.com people said they contain no idea about this topic. Proper management needed to reduce the possible impact of inundation. In future flood frequency also gradually increases due to geographical condition of the Bangladesh. Nageshwari Upazila is also vulnerable for this flood. Flood frequency also increases in this study area.

Magnitude of flood of recent time - Within the lessons part the level of the flood percentage of very high is $40 \%$, the percentage of high is $32 \%$, medium is $20 \%$ and the percentage of low is $8 \%$. From (Fig 6) respondent's opinion it can say that about $86 \%$ people livelihood unnatural by the floods adverse effects and about $14 \%$ people livelihood was not affect by the effects of flood. People realize, flood magnitude is very elevated within the recent time and on behalf of this cause flood impacts are many in this area.

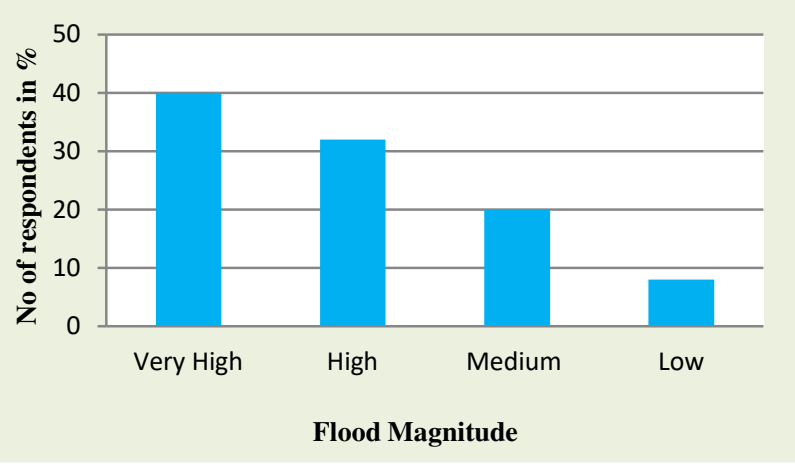

Fig 6: Magnitude of flood within recent time (Source: Field Survey-2019).

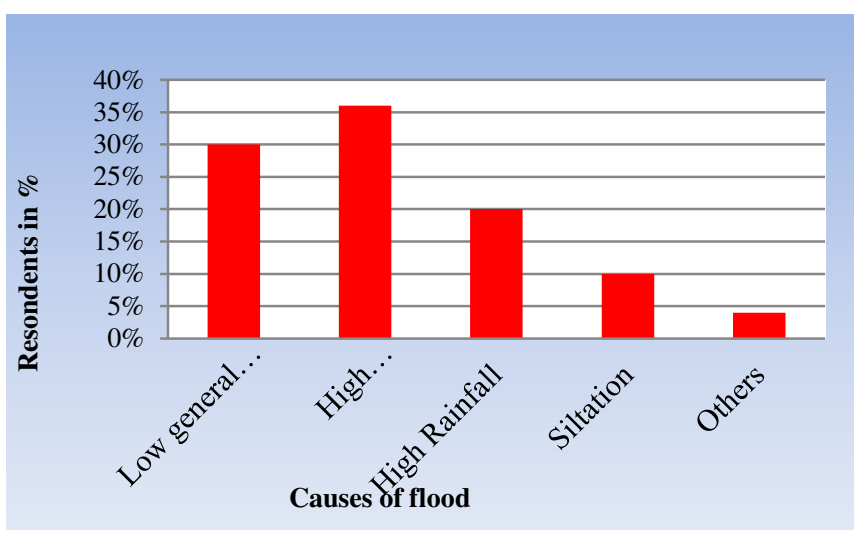

Fig 7: Causes of flood within the lessons area (Source: Field Survey-2019).

Causes of flood within the lessons area - From respondents opinion it is found that the majority of the floods are occurred because of high monsoon flow through the rivers. High rainfall also occurred every 
year within the lessons area. It is the primary cause for floods within the lessons area. From the people's perception high monsoon flow through the rivers is the major reason for flood (Fig 7). Around 30\% respondents said that flood occurred within the lessons area owing to little general topography and about $36 \%$ respondents said about high monsoon flow through the rivers. Moreover, $20 \%$ of the respondents said about high rainfall, $10 \%$ people said about siltation and $4 \%$ people said about others reason for flood occurrence.

Impacts of current flood - The study area is one of the mainly vulnerable areas of flood within that region. In every year flood occurred a vital impacts especially on the livelihood sectors. A large amount of the people directly depends on the agriculture sector in this area. Flood of this area mostly affect the agriculture sector (Fig 8). A large amount of the respondents of the lessons said that the agriculture product and livestock was the mostly affected during the flood. During survey almost $50 \%$ people said about flood impact on farming sector. 7\% people opined about loss of fisheries and $12 \%$ people argue about loss of livestock. Commnication problem is a big problem during the flood period. The majority of the road are damaged and community are not easily moved from any where. $6 \%$ people said about the impacts on road and transport. Almost 5\% people mention about impacts on health, $2 \%$ people said about river chanal migration, $5 \%$ people opined about water and hygiene and 3\% people said about impacts of floods in educational sector.

Rating of affected sectors - All respondents of households afore mentioned that "flood water entre into the crop land and cause giant damages of the money crops". One-fourth respondents said that "sometime flood happened suddenly and they could not collect their main staple crop in due time. As a result the total crop production goes to be damaged". Most affected sectors is agriculture sector from the people's perception (Fig 9). From the general survey in the study area more than $65 \%$ people are said about agriculture sector.This sector is most affected sectors due to flood rather than other.Moreover, 5\% people said about livestock sector , 8\% people said about communication sector, $3 \%$ people said about Health sector, $4 \%$ people said about education sector and $10 \%$ UniversePG I www.universepg.com people said about housing sector. Every crop has specific time duration to survive against water logging, but when this duration is over then the manufacture of crop gets affected severely. It is well known that flood is a long lasting type of disaster. Every responder said that previously there were some kinds of signs before any flood. However now a days, flood comes without any notice or early signs.

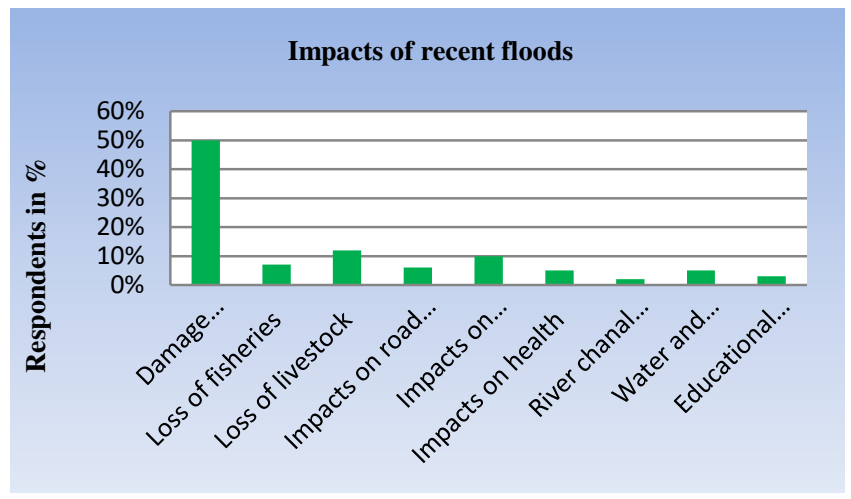

Fig 8: Different impacts of recent flood (Source: Field Survey-2019).

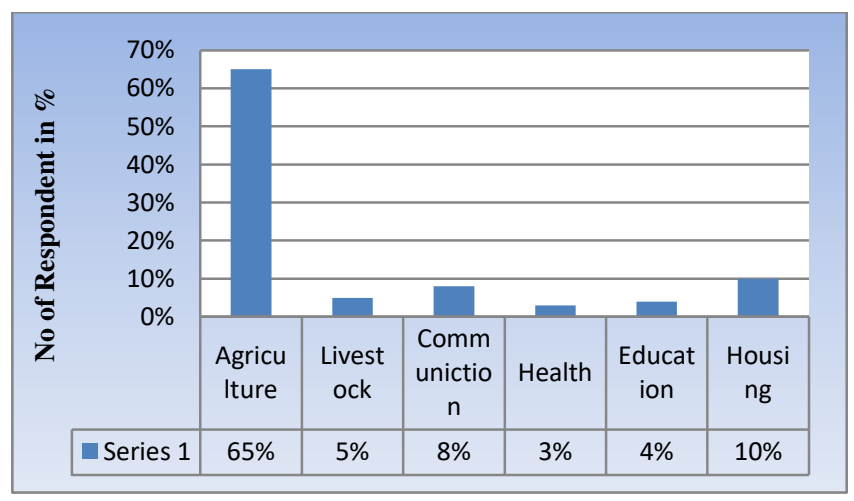

Fig 9: Most affected sectors due to flood (Source: Field Survey-2019).

Problems due to floods - As communication links and infrastructure like power plants, roads and bridges square measure broken and discontinuous, some economic activities could return to a standstill, individuals' square measure forced to go away their homes and traditional life is discontinuous. Scarcities of food caused by crop failure. In the time of flood people are become jobless that creates unemployment difficulty within the study area. During the flood period every of the roads were overflow by the flood water. Boat was the only vehicle to maintain social communication and to go away to any place from house. Problems due to flood is given below (Fig 10). The maximum people of the lessons area are poor therefore, the majority of the 
public were unable to manage or buy a personal boat. For this regions trans-port and social communication were much more difficult. From the people's perception within the lessons area, Almost 60\% people are said they face unemployment troubles within the time of flood. Food scarcity causes malnutrition, health problems, no choice in food preferences etc. This all are the possessions of flood. $25 \%$ people said about food scarcity problem, $10 \%$ said about communication problem and 5\% said about others problems within the lessons area. In the study area alternative basis of profits must be enriched through the government or NGOs. Proper food supply must be required to minimize food scarcity problem.

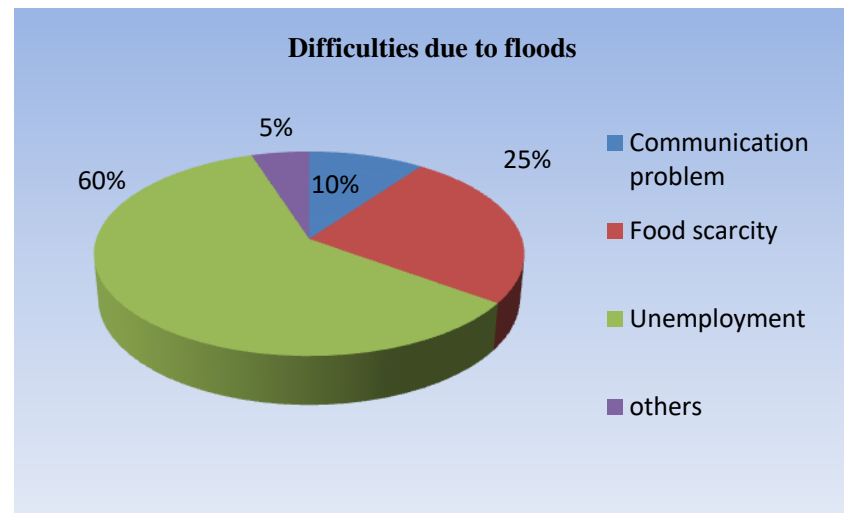

Fig 10: Difficulties due to floods within the lessons area (Source: Field Survey-2019).

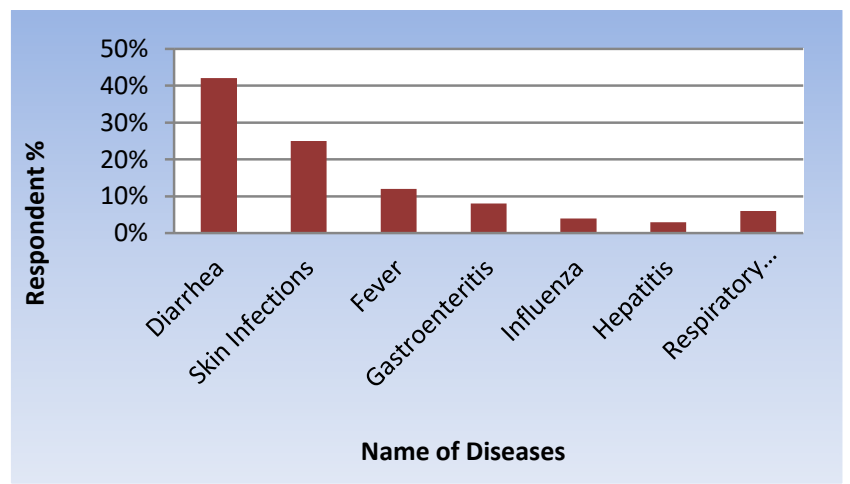

Fig 11: Common health problems due to flood (Source: Field Survey-2019).

People's Perception on water scarcity - During the flood times almost every tube well or the drinking water source was affected. Therefore it was very difficult to manage the secure consumption water. A large amount of the respondents said that, they collected water far from their residence or drank the flood water affected boiling it. Almost $82 \%$ people said they face water scarcity difficulty within the time of flood and $18 \%$ people said thay faces no water scarcity probem in the time of flood. Water and hygiene amenities are mostly affected sctor. During any flood most of the well goes below the flood water and for this reason safe water for drinking and different activities become unobtainable. To decrease the water scarcity problem local authority must be taken some initiatives to raise the height of tubewell. When tube well are not submerged that time community do not faces the water scarcity.

Common health problems due to flood - Flooding hazards always pose the outbreak of viral and fugal infectious diseases in Char area. Besides, weak socioeconomic status bear low health hygienic practice during flood and post flood period lead measurable health hazardous condition. While interviewing on flood borne diseases and observing some situational factors following diseases were identified (Fig 11). During this period, different water borne diseases like diarrhea, cholera, jaundice and skin related health problems are most commonly seen. Especially, children and aged people are most commonly suffered from these types of healthiness associated problems. Within the lessons part, $42 \%$ people said about diarrhea diseases, $25 \%$ people said about skin diseases. Moreover, $12 \%$ people said about fever, $8 \%$ said about gastroenteritis problem, $4 \%$ said about influenza,3\% said about Hepatitis and $6 \%$ people said about respiratory infections. The outbreaks diarrheal diseases are possible during flood and post flood conditions (Ahern et al., 2005).

Availability of flood shelter - Within Nageshwari area, flood shelter is not available comparing to population. People realize properly constructed flood shelters are needed for better safety. When flood shelter is available within the lessons part that time people are safe from flood impacts. About $12 \%$ respondents said that flood shelters with the limited facilities are available within the lessons area. Almost $88 \%$ respondents said flood shelters are not available to meet their residential support during flood. Available flood shelter requires to be recognized for the people. When flood shelters are available within the lessons area with proper management to save their life and property, people are interested to go away to flood 
shelter. From our field survey, the communities of this area were not forced to evacuate from their dwellings during last flood. There has no safe flood shelter that increases the suffering of the affected community.

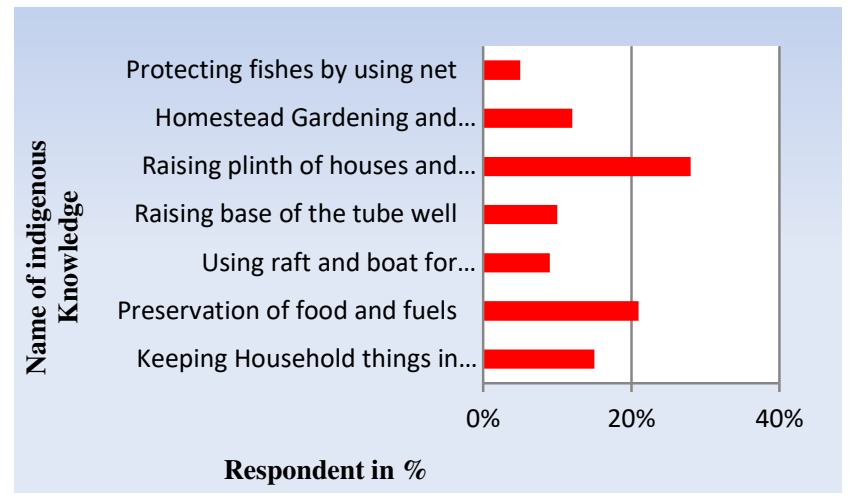

Fig 12: Indigenous knowledge practices by the local people (Source: Field Survey-2019).

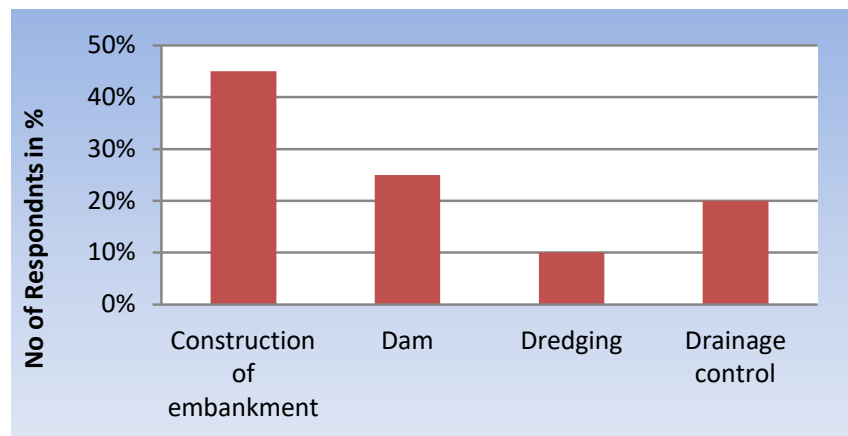

Fig 13: Scientific flood measures by the authority to diminish the flood (Source: Field Survey-2019).

Indigenous Practices - Indigenous data refers to the distinctive cognitive content existing at intervals and developed round the specific conditions of girls and men autochthonic to a specific geographical area. Within the lessons area people are applied some indigenous knowledge to alleviate the impact of downpour (Fig 12). In general, the indigenous knowledge of housing pattern reduces the vulnerability of floods. They plant different grass and plants within the stream bank for the protection of community properties. People prepare dry fish and grow different vegetables around homesteads for reducing the vulnerability. These practices ensure food safety within the lessons areas. In the study area almost $15 \%$ people said they keeping their household things in safe place, $21 \%$ people opined they preserve food and fuels to cope with the flood. Moreover, 9\% people argue they using raft and boat for transportation, $10 \%$ people said they raise their bottom of the tube-well, $28 \%$ people mention they raise plinth of houses and cattle shed, $12 \%$ people believed about homestead gardening and planting trees and $5 \%$ people said they suing net for protecting fishes. This indigenous knowledge helps the community to alleviate the flood. Few people also plant Banana trees which can prove useful during flood. People use these trees for making rafts which serve both as transport and as shelter during floods (Rasheduzzaman et al., 2021; Hakim, 2012).

Scientific flood measures by the authority - From the KII some scientific practices are found that are practiced by the authority to diminish the flood (Fig 13). Within the lessons area $45 \%$ respondents said about construction of embankment, 25\% opined about Dam, $10 \%$ mention about dredging, and 20\% argue about drainage project. Construction of embankment is a great initiative by the authority. But embankment is constructed for a limited portion of river side. A dam is a barrier that impounds water or underground streams. Dams typically serve the first purpose of retentive water, whereas alternative structures like floodgates or levees (also called dikes) area unit accustomed manage or forestall water flow into specific land regions. Flood control and emptying structures have conjointly been provided in major areas to form the areas flood free. Stream maintenance through dredging is additionally occurring in an exceedingly restricted case thanks to the high value. Within the lessons area above scientific practices are practiced by the authority to diminish the flood. When this practices are practiced properly that time community will be more resilient against flood.

Major initiative need to be taken to diminish flood problems - From the people's perception a large amount of the community realize that available training program needs to be in use to solve the flood problem. Awareness rising is an essential part to aware people about flood impacts. Education is necessary for every people. When people are being educative the greater part of peoples aware about problems and they obtain required steps to decrease the problems. From the people's perception major initiatives are training pro-grams, awareness rising, enhancing management system, involve people as a volunteer and education (Fig 14). From the general survey about $70 \%$ people said, they need awareness raising program about 
cyclone and cyclone warning. Moreover, 90\% people said about training program. While $80 \%$ people suggest involve people as a volunteer to decrease the problems. About $65 \%$ people said about enhancing management system. Whereas, $80 \%$ people said proper education can reduce the problems. When management committee must acquire required steps about management system that times many problems will be reduced.

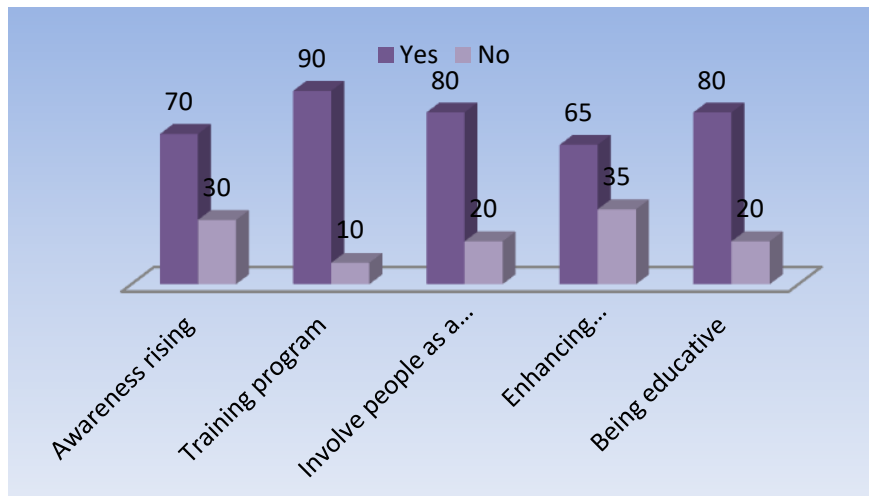

Fig 14: Major initiatives require to be taken to mitigate flood problems (Source: Field Survey-2019).

Early Warning and Dissemination Method - Within the lessons area the majority of the people received disaster warning by hand mike (Fig 15a \& b). Electricity is a problem to disseminate warning among community within the time of disaster. The reasons for not receiving warning messages by the break of the respondents were: (a) lived in remote areas, therefore might not be reached by megaphones or hand mike and/or (b) did not contain entrance to radio or television. People are not capable to recognize the warning. Early warning is a concern issue in disaster management field. About $52 \%$ people said they received warning by hand mike. Almost $20 \%$ respondents said they received warning by the local authority. Radio or Television is a method to disseminate warning in the time of disaster. But within the lessons area only $13 \%$ people received warning by radio or television. $9 \%$ people said they received warning by mobile phone and $6 \%$ people said they received warning by word of mouth. More than half of the communities are dissatisfied about receiving of early warning. Only $20 \%$ people are satisfied about early warning system. Almost $16 \%$ people have no comments about receiving early warning. Illiteracy, lack of awareness, receiving of warning and communication problem means that UniversePG I www.universepg.com some communities do not realize or follow the warnings. In study area many community do not recognize the warning. Bangladesh is now totally covered by mobile telecommunication networks; issuing flood warning messages via mobile phones is consequently a good option.

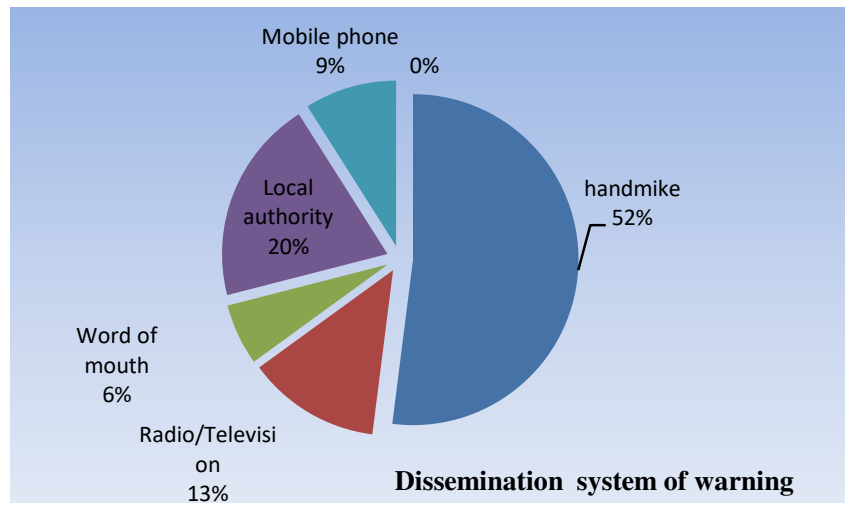

Fig 15: (a) Dissemination system of warming.

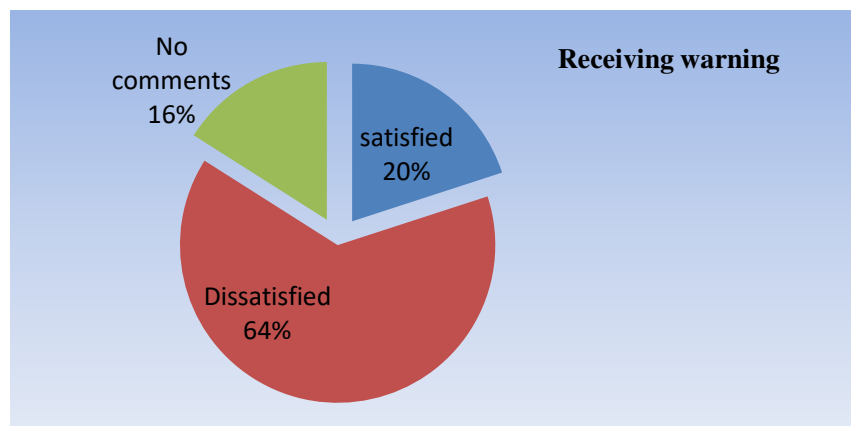

Fig 15: (b) Early warning dissemination and receiving status (Source: Field Survey-2019).

Respondent's Preparation to deal with flood Nageshwari Upazila is a flood prone area. It is most susceptible to inundation due to extreme precipitation, low lying area and river. A large amount of the people said that they are not prepared for an upcoming flood (Fig 16). Communities are not taken effective preparedness for flood. Here is no flood shelter (Nur et al., 2021). They acquire protection in high road, dam, matcha, roof, bed, etc. A large amount of the community does not save money for flood periods. As an outcome poverty and food uncertainty breaks out after flood within the area. With-in the lessons area $40 \%$ people said they have to do nothing for flood preparedness. $12 \%$ said about preserving vegetable seed and 5\% people said about store crop residues for livestock. Preserving food for livestock, making portable stove for cooking during flood, preserving of diversified vegetable seed and pure drinking water, etc. are 
the preparedness of flood. $5 \%$ people said about saving money. Moreover, $8 \%$ people said about making matcha, $15 \%$ people said about tree plantation. $12 \%$ people said about preserving dry food and $3 \%$ people said about early sowing.

Training Facilities on early warning or pre flood preparedness - In study area almost $75 \%$ respondents said they have not received any training on early warning or flood preparations (Fig 17). Only $25 \%$ people said they have received training from different organizations in a limited scale. More than half of the public said training program was insufficient for them. Training program is necessary for better resiliency in the area. But training facility is not proper rather than people expectation. A large amount of the people is

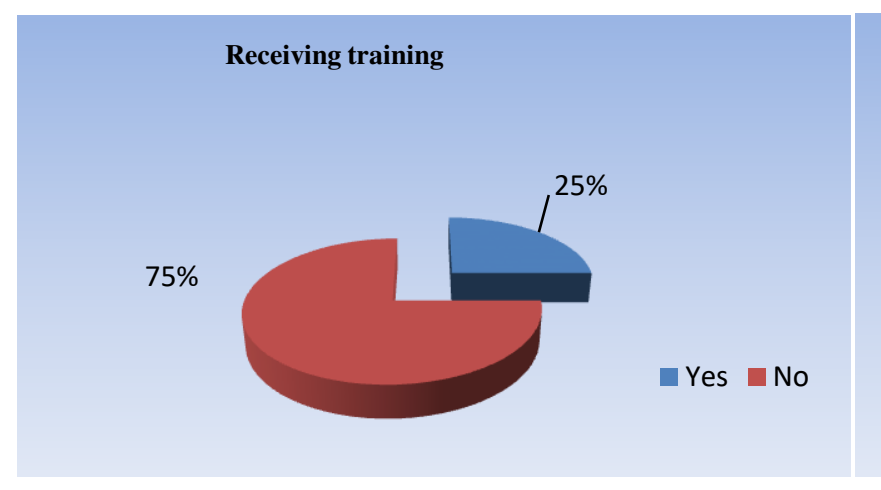

interested to exit to training. Peoples are realizing, training program is very much effective for enhancing community resiliency to disaster. Almost $30 \%$ people said training program was sufficient for them. $20 \%$ people had no comments on training facilities.

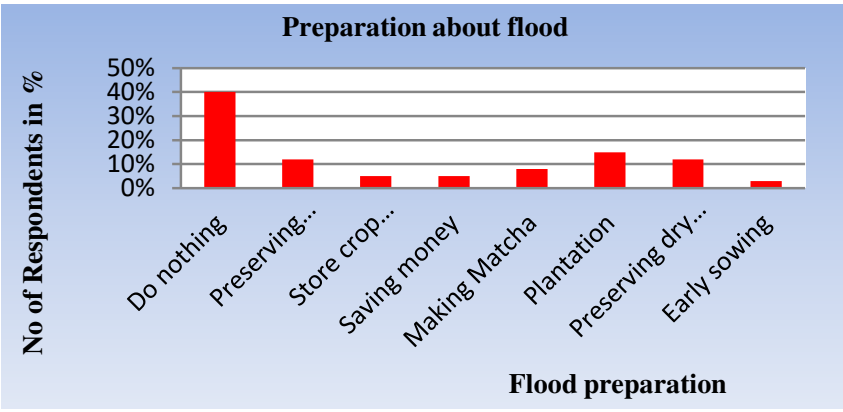

Fig 16: Respondent's preparation to deal with flood (Source: Field Survey-2019).

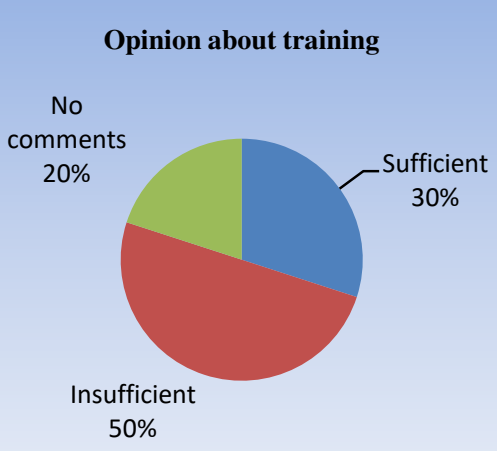

Fig 17: Status of training facilities (Source: Field Survey-2019).

\section{Existing Training Facilities for Flood Resiliency -}

Rangpur Dinajpur Rural Service (RDRS) organized many training within the study area. Almost $55 \%$ training conducted by RDRS (Fig 18). In the study area $10 \%$ training conducted by ASA. Microfinance is that the core program of ASA with eight million shoppers across Asian country, and it's additionally implementing variety of non-financial programs: Education, Healthcare, Sanitation, and Agriculture etc. SOLIDARITY implemented the project since 2012. SOLIDARITY arranged $10 \%$ instruction within the study area. Almost $5 \%$ training are conducted by MGSKS. Chars Livelihoods Programme is also participate a responsibility to train people about disaster. $20 \%$ training is conducted by CLP. Training program is so much poor rather than expectation. The main objectives of the programme area unit to boost social and economic assets, scale back environmental and economic risk and increase access to markets and services (Brocklesby \& Hobley, 2003).

UniversePG I www.universepg.com

\section{Local Government/NGOs initiatives to diminish the}

flood impacts - Construction of embankment is a great initiative by the local government. Raising plinth level is also another initiative that is taken by different organizations. Geobags square measure sand-filled high strength geo textile baggage square measure accessible within the varied sizes and square measure employed in bank, beach protection and offshore jetty. Our Geobags for water course Banks and Flood Controls have high strength and sturdiness for holding all types of sand particles. Local Government/NGOs initiatives are given below (Fig 19). Flood water protected tube well, Drainage construction, awareness raising, helping and rescue people, Dam, this all are the initiatives taken by the local government or NGOs to decrease the flood impacts. Almost $40 \%$ people said about construction of embankment within the lessons area, 32\% people opined about geo bag that are use within flood protection system. Moreover, $47 \%$ people said about raise plinth level, $42 \%$ people said flood water protected 
tube well, 30\% people argue about Dam, 20\% people said about drainage construction, $35 \%$ mention about awareness raising, 25\% people opined about helping and rescue people this all initiatives are in use by the local government/NGOs. People expectations are high rather than their initiatives. When all initiatives are taken fully by the local government or NGOs that time the community will be more resilient against flood.

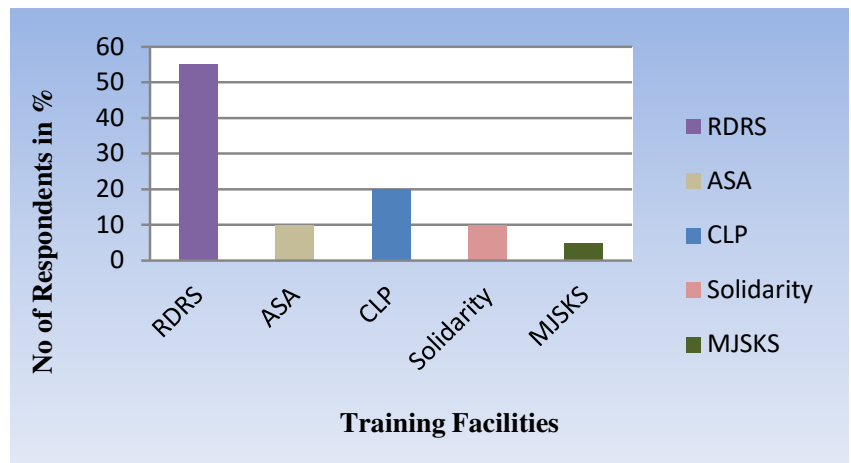

Fig 18: Existing Government and non-government training facilities for flood resiliency within the lessons area (Source: Field Survey-2019).

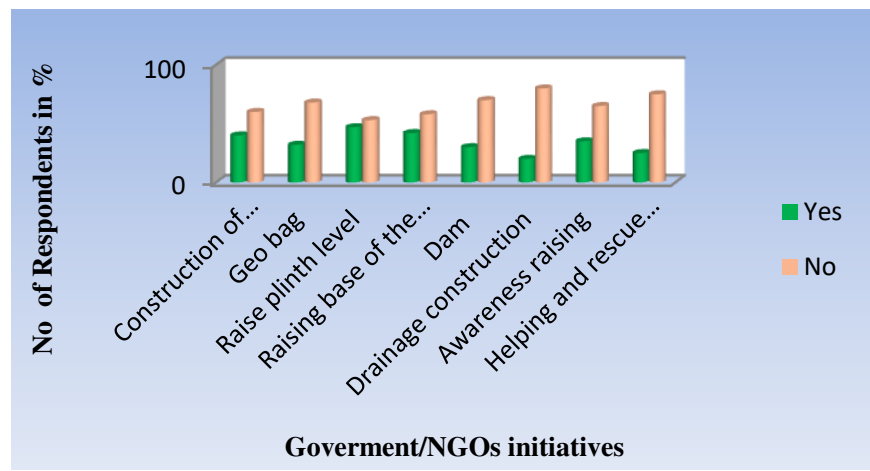

Fig 19: Local Government/NGOs initiatives to diminish the flood impacts (Source: Field Survey-2019).

\section{Adaptation techniques taken for mitigating flood}

For livelihood - People in study area have adopted diverse kind of indigenous strategies to protect crops, including the variety of right type of crop varieties that suit the time frame of floods and the floodwater level as well as the physiographic and soil circumstances of the area. Significant numbers of farmers used to follow the traditional crop calendar of the country. They conjointly use to cultivate mustard, potatoes, pulses, spices, sweet potatoes, vegetables and wheat through-out the Rabi (post-flood) season. Because of flooding, several farmers like sugarcane and jute to paddy as they survive in high floodwater. Within the lessons area, farmers cultivate Boro and other crops during the Rabi UniversePG I www.universepg.com term and within the Kharif term; they prefer Jagon to cultivate different vegetables in (Fig 20). Adaptation techniques can reduce the failure of life, property, health and others. Within the lessons area $45 \%$ people said they take measures about seed preservation, 15\% people said they search alternative basis of earnings to mitigate the flood, $17 \%$ people said they take, initiatives for food and fuel preservation, $23 \%$ people they have not taken any measures for mitigating flood. The storing of food, fuel and water is a difficult challenge for sufferers of a flood. People choose and use big Motki/Kola (made by mud) and polythene bags to stockpile dry food and seed. In most homes, the storing place is more than the conventional floor; such places stay safe till there's high floodwater.

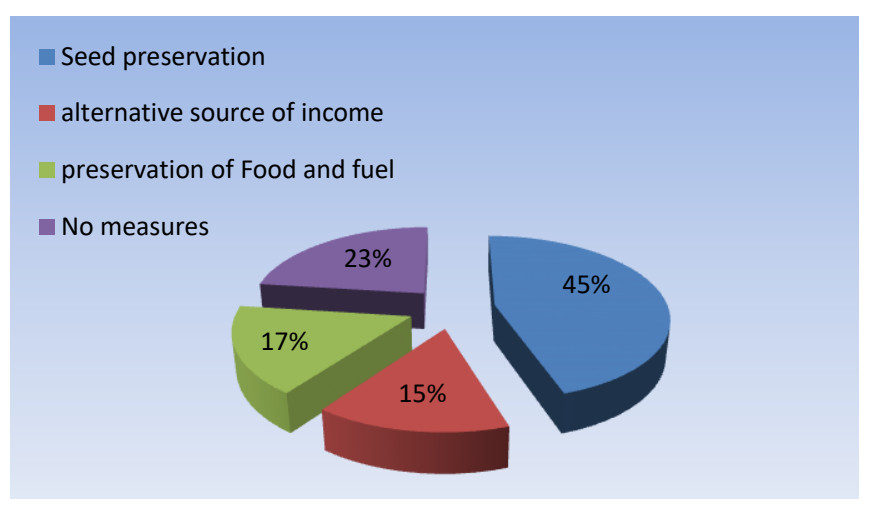

Fig 20: Adaptation techniques for livelihood purpose (Source: Field Survey-2019).

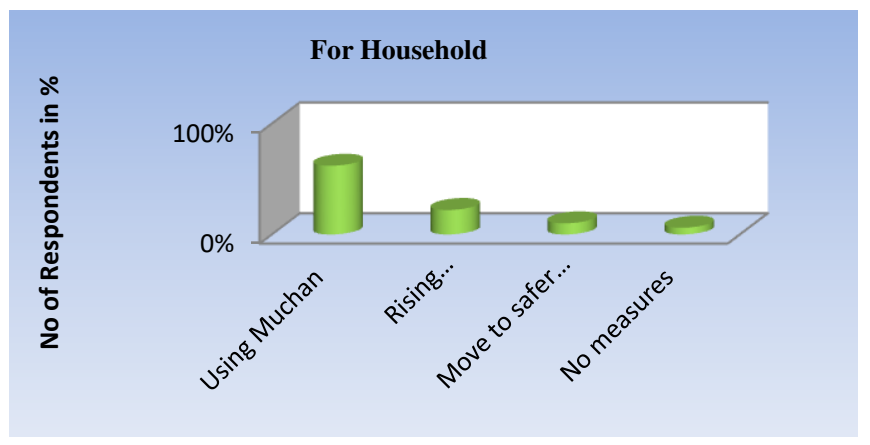

Fig 21: Adaptation techniques for household items (Source: Field Survey-2019).

For Household items - When floodwater increases, people usually prepare a Muchan inside the house and most houses within flood-prone area have a Pataton that is use to accumulate food, fuel and water. The study showed that greater part of the respondent (62\%) within the lessons area use Muchan to protect food, fuel and water (Fig 21). For the period of elevated flood people move these things to safer places to miti- 
gate the losses. Within the lessons area, 10\% people said they move the things to safer places to mitigate the flood impacts. $22 \%$ people said they raise their homestead to defend the upcoming flood. $6 \%$ people said they have taken no measures for household items to defend the flood losses. Flood impacts are many within the lessons area; people are taken some adaptation techniques to decrease the impacts. Though these techniques are not properly fill the demand. Government initiatives require to be improved to diminish the flood.

For Water and hygiene - Especially when the flood water recede, many water bear disease such as diarrhea, dysentery and other skin diseases are common. Among others, women and kids have a high prevalence of water bear disease. People rely greatly on their own traditional knowledge of treating these diseases. Most people know about oral saline and they buy saline packets from the local market and many mentioned that if need be they also know how to formulate saline at home. Adaptation techniques for water and sanitation are helpful to diminish the losses of foods. When people are aware about diseases that time they are not take the contaminated water. Adaptation techniques for water and hygiene are given below (Fig 22). Within the lessons area, 24\% people said they raise the tube well, $15 \%$ opined they raise the ground of toilets, $22 \%$ people argue they boiling the water before drink, $5 \%$ people said they are purifying water by tablet and $34 \%$ people mention they have not taken any measures for water and hygiene purposes.

Flood Resiliency Techniques - There are different processes of managing flood. About 35\% respondents said loan from bank is the most familiar management system to manage flood (Fig 23). 17\% people said about river dredging and $30 \%$ people said about construction of embankment. Moreover, $10 \%$ people said planting trees is the method to manage flood and only $8 \%$ people said about dam making. When these kinds of things are accessible within the lessons area that time flood will be managed. Road construction also needed in the char area (Hossain et al., 2015). Flood Management measures are aimed at reduction of damage and harmful effects, and formation of an environment for enhanced economic activity. Total Flood Control is neither possible nor desirable. Flood manaUniversePG I www.universepg.com gement minimizes potential flood damage. Flood Management Create flood-free land for an improved living environment (Nishat, 2004).

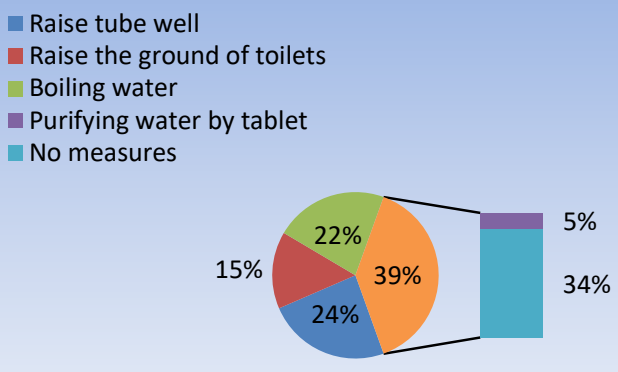

Fig 22: Adaptation techniques for water and hygiene (Source: Field Survey-2019).

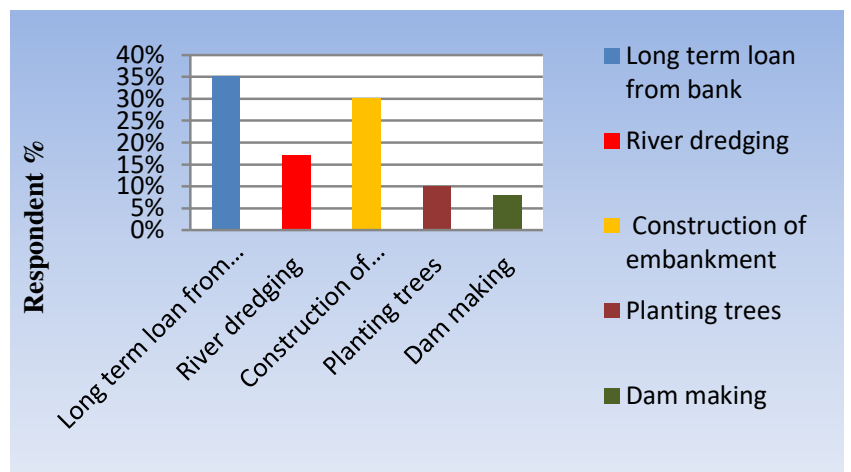

Fig 23: Flood resiliency techniques (Source: Field Survey-2019).

\section{CONCLUSION AND RECOMMENDATIONS:}

The study has been accomplished to identify the flood hazards as well as flood impacts at Nageshwari Upazila. Flash flood is individual of the devastating natural disasters within the northern area of Bangladesh. Nageshwari Upazila is a probable flash flood prone area. From the general survey, 50\% people opined flash floods are occurred within this area. From the overall survey in the study area more than $65 \%$ people are concerned about agriculture sector. This sector is most affected sectors due to flood rather than other hazards. In Nageshwari area, flood shelter is not available comparing to population. People realize properly constructed flood shelters are needed for better safety. $88 \%$ respondents said flood shelters are not available to meet their residential support during flood. $60 \%$ people said they face unemployment difficulty within the time of flood. The majority of the road are susceptible to damage and people can not easily moved from any where. $6 \%$ people said about the impacts on 
road and transport. During flood the majority of the tube well is inundated by flood water. Almost $82 \%$ people said they face water scarcity problem in the time of flood. For flood mitigation purposes, people are applied indegenous knowledge and authority are practices some scientific practice. From the field survey almost $28 \%$ people raise plinth of houses and cattle shed. Construction of embankment is a great initiative by the authority. Early warning system is not so good. Only $20 \%$ people are satisfied about early warning system. Peoples are not conscious on early warning dissemination and reception. To overcome from the constraint awareness raising program, training program, volunteer involvement, enhancing management system and proper education should be enhance to construct a resilience community. Flood is the common disaster within the northern section of Bangladesh. Although it is not achievable to stop the incidence of flood but proper plan, preparedness, adaptation techniques, management and human combined contribution may decrease the impacts of floods and could enhance the better community resiliency.

From overall observation, discussion and analysis; the following recommendations are made for remedy of the troubles and to decrease the flood impacts for enhancing community resiliency to flood:

- Construction of house should be used durable materials and away from the flood prone area and the height from the flood level must be considered.

- Construction of Flood shelter should be in proper design and amount of shelter should increase.

- Construction of dams should be considered to trap the excess water. This could be use for irrigation.

- Tree plantation requires being encouraged among the village people outside the community areas that should protect or minimize the flood impacts.

- Government and key stakeholders should engage the communities and local authorities in making them attentive of the flood risk in sight of the climate variability.

- The Ministry of Agriculture and Cooperatives should, through Extension Services encourage communities to increase cultivation and tree plan- tations on the upland in regulate to enhance food safety and household level.

- Government and non-governmental organizations should take some actions for enhancing people's alternative job in the time of flood.

- Raise the bottom of tube well and toilet must be required to secure the safe drinking water.

- Early Warning signal dissemination system should develop and spread out for flood forecasting in due time to the people.

- Spatial initiative should take for rural and char area community such as colorful hot air balloons' can be used to transfer flood warning messages in those areas.

- Construction of embankment must be needed in possible flood prone region.

- Improvement in drainage scheme within the area so that flood waters may be quickly drained out subsequent a flood incidence.

- Awareness raising program and early warning method should be developed for flood readiness and establish faculty tending team, faculty disaster management team and instruct all of them.

\section{ACKNOWLEDGEMENT:}

We want to articulate our deep gratitude and acknowledgement to the faculty of Environmental Science and Disaster Management of Patuakhali Science and Technology University for facilitating this research. We would approximate to especially thank the cordial, hospitable and cooperative participants of this investigate for their time and efforts where the questionnaires were administered and without whom this research would not have been possible. Some other people also helped us at different stages of this research. Thanks also to the reviewer for their constructive comments and valuable suggestions.

\section{CONFLICTS OF INTEREST:}

The authors declared no possible conflicts of the interest with respect to the research, authorship and publication of this article.

\section{REFERENCES:}

1) Ahern et al. (2005). Global health impacts of floods: epidemiologic evidence. Epidemiologic reviews, 27(1), pp.36-46.

https://doi.org/10.1093/epirev/mxi004 
2) Ahmed, A.U. and Mirza, M.M.Q. (2000). Review of causes and dimensions of floods with particular reference to flood. https://doi.org/10.1051/e3sconf/20160710003

3) Ali, A. (1996). Vulnerability of Bangladesh to climate change and sea level rise through tropical cyclones and storm surges. In Climate change vulnerability and adaptation in Asia and the Pacific (pp. 171-179). Springer, Dordre. https://doi.org/10.1007/978-94-017-

4) AM et al. (2003). Floods in Bangladesh: A comparative hydrological investigation on two catastrophic events. Research report of the Faculty of Environmental Science and Engineering, Okayama University, 8(1), pp.53-62.

5) Banerjee, L. (2007). Effect of flood on agricultural wages in Bangladesh: An empirical analysis. World develop., 35(11), pp.1989-2009. https://doi.org/10.1016/j.worlddev.2006.11.010

6) BBS, (2011). Population and Housing Census Bangladesh Bureau of Statistics and Information Division, Ministry of Planning.

7) Brocklesby, M.A. and Hobley, M. (2003). The practice of design: developing the Chars Livelihoods Programme in Bangladesh. Journal of the Development Studies Assoc., 15(7), pp.893-909.

8) Brouwer et al. (2007). Socioeconomic vulnerability and adaptation to environmental risk: a case study of climate change and flooding in Bangladesh. Risk Analysis: an International Journal, 27(2), pp.313-326. https://doi.org/10.1111/j.1539-6924.2007.00884.x

9) Cutter, S.L. (1996). Societal responses to environmental hazards. International Social Science Journal, 48(150), pp. 525-536.

10) Few et al. (2004). Floods, health and climate change.

11) Hakim, S. (2012). Reduction of flood risk by indigenous knowledge at Alekdiar Char of Shibalaya Upazila in Manikganj district (Doctoral dissertation, BRAC University). http://hdl.handle.net/10361/2725

12) Haque, C.E. (1993). Flood prevention and mitigation actions in Bangladesh: the 'sustain-able floodplain development' approach. Impact Assessment, 11(4), pp.367-390.
13) Hossain et al. (2012). Annual flood report 2012. FFWC, BWDB, Dhaka, Bangladesh.

14) Hossain et al. (2013). Effects of flooding on socio-economic status of two integrated char lands of Jamuna River, Bangladesh. Journal of Environmental Science and Natural Resources, 6(2), pp.37-41. https://doi.org/10.3329/jesnr.v6i2.22093

15) Islam, S. (2017). Assessment of the Impact and Management of Flood, Drought and River Bank Erosion: A Case Study of Char Land Peoples of Gangachara Upazila, Rangpur District, Bangladesh. Imperial Journal of Interdisciplinary Research, 3(4), pp.96-111.

16) Khalequzzaman, M.D., (1994). Recent floods in Bangladesh: Possible causes and solutions. Nat. Hazards, 9(1), pp.65-80.

https://link.springer.com/article/10.1007\%2FBF00 $\underline{662591}$

17) Mirza, M.M.Q. (2003). Three recent extreme floods in Bangladesh: a hydro-meteorological analysis. In Flood problem and management in South Asia (pp. 35-64). Springer, Dordrecht. https://doi.org/10.1007/978-94-017-0137-2_2

18) Mirza, M., (2007). Climate change, adaptation and adaptive governance in water sector in South Asia. Phys Sci Basis, pp.1-19.

19) Mohapatra, P.K. and Singh, R.D., (2003). Flood management in India, flood problem and management in South Asia (pp. 131-143). Cham: Springer. https://doi.org/10.1023/A:1021178000374

20) Moniruzzaman et al. (2014). Assessing the Damage and Recovery at Household Level: A Case Study of Cyclone Aila Affected Area. Asa University Review, $8(1)$.

21) Nasreen et al. (2013). Climate Change and Livelihood in Bangladesh: Experiences of people living in coastal regions. Proce. Of Int. Con. of Building Resilience, pp.1-25. https://doi.org/10.1016/j.proeng.2018.01.020

22) Nishat, A. (2004). Poverty and Environment: role of microfinance. Bangladesh: IUCN-The World Conservation Union. https://doi.org/10.1016/j.jclepro.2016.10.128

23) Nur MNB, Rahim MA, and Rasheduzzaman M. (2021). Identifying cyclone shelter facilities and 
limitations for enhancing community resiliency in coastal areas of Bangladesh, Asian J. Soc. Sci. Leg. Stud., 3(4), 107-118.

https://doi.org/10.34104/ajssls.021.01070118

24) Raghunath, H.M. (2009). Revised edition, Hydrology: principle analysis and design, New Delhi. New age international publishers.

25) Rahman, (2014). An analytical study of flood management in Bangladesh. IOSR Journal of Engineering (IOSR-JEN), 4(1), pp.01-06.

26) Rahman, S.U. (2014). Impacts of flood on the lives and livelihoods of people in Bangladesh: A case study of a village in Manikganj district (Doctoral dissertation, BRAC University). http://hdl.handle.net/10361/3802

27) Rahman, R. and Salehin, M. (2013). Flood risks and reduction approaches in Bangladesh. In Disaster risk reduction approaches in Bangladesh (pp. 65-90). Springer, Tokyo. https://doi.org/10.1007/978-4-431-54252-0_4

28) Rasheduzzaman M, Uddin A, Shamsuzzoha M., and Rahman MA. (2020). Analysis of cyclone shelter patterns to build a better shelter management: a case study of Bangladesh southern region, Asian J. Soc. Sci. Leg. Stud., 2(3), 47-55. https://doi.org/10.34104/ajssls.020.047055

29) Ravallion, M. (1990). Rural welfare effects of food price changes under induced wage responses: theory and evidence for Bangladesh. Oxford Economic Papers, 42(3), pp.574-585. https://doi.org/10.1093/oxfordjournals.oep.a041964

30) Sinclair, S. and Pegram, G. (2003). A Flood Nowcasting System for the eThekwini Metro, Volume 1: Urgent Nowcasting using Radar-An Integrated Pilot Study. Water Research Commission (WCR). Silowa Printers South Africa.

31) Torry et al. (1979). Anthropological studies in hazardous environments: Past trends and new horizons, Current anthropology, 20(3), pp.517540. https://www.jstor.org/stable/2742110

32) Varley, A. (1994). The exceptional and the everyday: Vulnerability analysis in the international decade for natural disaster reduction. $J$. Wiley.

Citation: Nur MNB, Rahim MA, and Rasheduzzaman M. (2021). Flood impacts analysis and mitigation approach towards community resiliency at Nageshwari upazila, Kurigram, Asian J. Soc. Sci. Leg. Stud., 3(5), 178-192. https://doi.org/10.34104/ajssls.021.01780192 @) $\underset{\mathrm{BY}}{\mathrm{O}}$ 